\title{
Evidence of Macroeconomic Policy Effects over Company-Sector Stock Returns
}

\author{
Evidência dos Efeitos de Política Macroeconómica sobre os Retornos de Ações \\ de Empresas-setores
}

\author{
Mara Madaleno ${ }^{1}$ \\ Carlos Pinho ${ }^{2}$
}

\begin{abstract}
Given that stock markets may act as an economy mirror, it is explored the sensitivity of company-sector-specific stock returns to macroeconomic news reflecting different economic environments for the UK, US, Germany, Japan and Australian markets between March 1993 and February 2013 using monthly data. Results seem to indicate that portfolio investors need to be aware that movements in the market index is the best predictor to forecast stock returns of individual companies and sectors in developed economies. Sentiment influences individual company's returns of the utilities sector, even if these are considered of limited growth and stable earnings, for UK, USA and Australia, turning investor confidence a relevant variable to be included. Information increases about industrial production have no influence on company and sector stocks, thus not affecting investor's decision in developed countries. As for Japan, results seem to indicate that the higher the need of oil imports of a country, the higher will be the positive impact of oil price changes over company returns. Finally, the riskless interest rate has no effect on sector stock returns independently of the country under analysis. For developed economies, we confirm the finding that stocks cannot be used as a hedge against inflation.
\end{abstract}

Keywords: Factor Models, Macroeconomic Variables, Stock Returns, Firm Performance, Growth Determinants

Resumo: Dado que os mercados de ações podem funcionar como um espelho da economia, explora-se a sensibilidade dos retornos de ações de empresas-setores específicos aos impactos de notícias macroeconómicas refletindo diferentes ambientes económicos para os mercados do UK, EUA, Alemanha, Japão e Austrália entre Março de 1993 e Fevereiro de 2013 usando dados mensais. Os resultados obtidos sugerem que os investidores precisam de estar atentos aos movimentos do índice de mercado pois este parece ser o melhor indicador previsional dos retornos de ações tanto de empresas individuais como de setores em países desenvolvidos. O sentimento influencia os retornos das empresas individuais no sector das "utilities", mesmo sendo estes considerados de crescimento limitado e ganhos estáveis para o UK, EUA e Austrália, evidenciando a relevância de incluir a variável confiança do consumidor. Novidades relacionadas com a produção industrial parecem não ter qualquer influência nos retornos de empresas e de setores, e assim não afetam as decisões dos investidores nos países desenvolvidos. Relativamente ao Japão, os resultados parecem indiciar que quanto maior for a necessidade de importações de petróleo de um país, superior será o impacto positivo de alterações do preço do petróleo sobre os retornos das empresas. Finalamente, a taxa de juro sem risco não mostra evidência de impacto nos retornos por sector independentemente do país em análise. Para as economias desenvolvidas, conseguimos confirmar resultados prévios de que as ações não conseguem cumprir a função de cobertura de risco face à inflação.

Palavras-Chave: Modelos de fatores, Variáveis Macroeconómicas, Retornos de Empresas, Performance de Empresas, Determinantes do Crescimento

JEL classification: C22; E0; G10

\footnotetext{
${ }^{1}$ Universidade de Aveiro

${ }^{2}$ Universidade de Aveiro
}

Revista de Estudos Sociais | Ano 2014, N. 31, V. 16, Pag. 3 


\section{INTRODUCTION}

Companies need to survive and gain competitive advantage in a volatile global environment. For this, managers need to understand not only the drivers of organizational performance, or else, individual risk, as well as the drivers of macroeconomic performance, or their market risk. Internal growth and success are reflected on stock market quotes which then explain investors' behaviors. But company growth is not only due to internal factors, it also depends on general macroeconomic conditions. This impacts investor's decision of investment, determining the future company performance. As such, macroeconomic variables and their effects on stock returns are interesting for scholars, investors, policy makers and corporate managers, given that the overall economy affects business by disturbing the smoothness of trade. Essentially, this study aims to improve investors' understanding and evaluation of the relevant stock returns to the systematic influences of macroeconomic factors. The derived information about the relationship between macroeconomic variables and stock market performance can enable investors to make optimal decisions in their global business investments. Given that systematic risk is induced by unanticipated fluctuations in macroeconomic factors and can't be diversified stocks markets should react to these changes.

Previous authors' studies allow us to state that the stock market and the overall economy are significantly related (Kuwornu and Owusu-Nantwi, 2011; Kemboi and Tarus, 2012; Tangjitprom, 2012; Gupta and Reid, 2013). This research targets to identify the effects of selected macroeconomic variables including oil price changes, inflation rate, industrial production index, market interest rate, market stock index and consumer confidence index on stock returns of 250 companies from 10 different sectors. We have chosen to work with data from 2 European countries (UK and Germany) and three world developed countries (USA, Australia and Japan) on the basis of monthly returns for the period between March 1993 and February 2013. For all countries individual company data as well as their sector stocks representatives are considered. This choice is due to the fact that developed countries' financial markets are observed to be more explained compared to other financial markets. Akbar et al. (2012) emphasize the popularity in studying the relationship between macroeconomic growth and stock market performance. Fama (1990), and more recently Binswanger (2000), state that stock markets are mainly affected by the surrounding economy and so useful to predict future economic conditions. However, each country and stock exchange possesses unique determinants and for the same considered variables, we may observe different answers. So, predictions of future trends of macroeconomic variables are helpful to understand the leading direction of stock returns. Results taken from factor models empirical estimation may be summarized as follows. Market index is the variable which most influences both companies and sector stock index returns for all the countries under study. There is no linear evident relationship between the rest of the macroeconomic variables and stock returns. 
Results cannot be generalized in terms of sectors or countries. Results suggest the importance of the inclusion of the consumer confidence index as an important macroeconomic variable affecting company's stock returns. Inflation, industrial production, market index and oil prices have a positive and statistically significant effect over developed sector stock market index returns. It is shown that insignificant beta coefficients estimates obtained are not due to a bad choice of repressors, but yes to the instability of beta coefficients estimates throughout time which leaves room for future work. This paper improves on earlier efforts by using different measures of macroeconomic news and by considering a set of different countries, where the emphasis is taken over individual company and sector stocks.

The findings of this study are expected to support the theoretical framework of the determinants of stock market movements from the developed economies perspective, given the policy implications undertaken from the analysis. The rest of the work develops as follows. Section 2 provides a brief literature review, where section 3 presents the methodology and data used for the empirical results presented in section 4 and in light of the attained results; its main implications are to be discussed. Finally, section 5 concludes.

\section{LITERATURE REVIEW}

The stock market plays an important role in the development of an economy (Bencivenga et al., 1996; Sharpe, 2002; Jones and Wilson, 2006). Capital markets quicken economic growth by enhancing mobilization of domestic and foreign resources and easing investment (Bencivenga et al., 1996). While Sharpe (2002) got a negative relation between expected long-term earnings growth and expected inflation, Jones and Wilson (2006) observed that inflation adjustments can weakly estimate stock returns. Capital markets also provide an avenue for growth oriented companies to raise capital at low cost (Marone, 2003), reduces reliance on bank finance which is susceptible to interest rate fluctuations, and provides a channel for foreign capital inflows (Yartey, 2008).

We may find empirical studies stating that there is no impact of specific macroeconomic variables over stock returns, but a lot more of these state that in fact there is a statistically significant relationship. Kandir (2008) uses monthly data from July 1997 to June 2005 and multiple regression models for Turkey, to suggest a negative impact of interest rates on stock returns. Industrial production, money supply and oil prices don't show any significant influence on stock returns. Also Kuwornu and Owusu-Nantwi (2011) found no significant influence of oil prices over stock returns. The authors use maximum likelihood estimation to conclude for the positive impact of the inflation rate (CPI consumer price index), and a negative one of the exchange rate and Treasury bill over stock returns for Ghana. Using ten years of data, from June 1998 to June 2008 in the Pakistani market, Hasan and Javed (2009) evaluated macroeconomic variables (inflation, industrial production, oil prices, short term interest rate, exchange rates, foreign portfolio investment and money supply) and equity prices by using several linear time series models. Oil prices and

Revista de Estudos Sociais | Ano 2014, N. 31, V. 16, Pag. 5 
inflation are detected as no significant but interest rate (IR), exchange rate and money supply appeared to be significant in the long run. For the same market, Nishat and Shaheen (2004) took data from 1973 to 2004, and employ the vector error correction model (VECM) and Granger-causality. They found that industrial production is the largest positive and inflation is the largest negative influencing factors of stock prices. Sohail and Hussain (2009) found that inflation negatively influences stock returns while there are positive influences of money supply, industrial production and real effective exchange rate on stock prices in the Lahore stock exchange from December 2002 to June 2008.

Özlen and Ergun (2012) study macroeconomic variables and their effects on stock returns of 45 companies from 11 different sectors in Turkey. The autoregressive distributed lag method is employed for monthly data spanning from February, 2005 to May, 2012. Overall results indicate that exchange rate and interest rate are more significant factors in stock price fluctuations of companies, then inflation rate, current account deficit and unemployment rate. According to Rjoub et al. (2009) empirical analysis, it seems to exist a relationship between macroeconomic variables including interest rate, unanticipated inflation, risk premium, exchange rate, money supply, unemployment rate and the Istanbul Stock Market (ISE) from January 2001 to September 2005 by using the arbitrage pricing theory (APT) model, correlation among explanatory variables and portfolios regression. For this same market, Gencturk (2009) studied the relations between stocks in ISE and macroeconomic variables by considering crisis periods and normal periods. Therefore, ISE-100 index is taken as the dependent variable; and treasury bond interest rates, consumer price index, money supply, industrial production index, dollar, gold prices are taken as independent variables. Sayılgan and Süslü (2011) analyzed the influence of macroeconomic factors on stock returns in emerging market economies using panel data from 1996 to 2006. Stock returns are found to be significantly influenced by exchange rates, inflation rates and the S\&P 500 Index while returns are not influenced by interest rate, gross domestic product, money supply and oil prices. Hosseini et al. (2011) studied the relationships between stock market indices and four macroeconomics variables including crude oil price, money supply, industrial production and inflation rate in China and India for the period January 1999 to January 2009. Results suggest both long and short run linkages between macroeconomic variables and the stock market index in both countries. One year after, Quadir (2012) investigates the effects of macroeconomic variables on stock returns of Dhaka Stock Exchange between January 2000 and February 2007, using monthly time series data and the Autoregressive Integrated Moving Average (ARIMA) model. Although results indicate a positive relationship between Treasury bill interest rate and industrial production with the market index stock return, coefficients turned out to be statistically insignificant.

Recently, Tangjitprom (2012) reviews a number of studies on macroeconomic factors and stock returns. Following the author, macroeconomic variables are classified into four groups: variables reflecting general economic conditions, variables related to interest rate and monetary policy, variables concerning price level, and variables concerning international 
activities. He concludes that various studies on macroeconomics factors and stock returns have employed different methodologies based on their purposes and interpretations and that despite mixed results, most studies have shown evidence for a significant relationship between macroeconomic variables and stock returns. Attending only to the energy sector, Zhu (2012) studies the impact of macroeconomic factors on returns in the Shanghai stock market (SEE). His findings reveal that exchange rate, exports, foreign reserve and unemployment rate impact stock returns in the energy sector. Benakovic and Posedel (2010) analyzes returns on fourteen stocks of the Croatian capital market from January 2004 to October 2009. Results show that the market index has the largest positive statistical significance for all stocks and returns. Interest rates, oil prices and industrial production also showed a positive relation to returns, while inflation had a negative influence. Gupta and Reid (2013) use a Bayesian vector autoregressive analysis to explore the sensitivity of industryspecific stock returns to monetary policy and macroeconomic news in South Africa, to find that in addition to the monetary policy surprises, the CPI and producer price index (PPI) affect stock returns significantly.

Considerable attention has been devoted to the relationship between stock markets and economic growth. However, there is still little empirical work on the determinants of stock market development in developing economies as well as the determinants of individual company stocks. Moreover, country specific data usage is necessary to determine the relationship between macroeconomic factors and securities market development because it is presumed that the determinants of securities market development vary from country to country depending on the nature of regulatory mechanisms, economic policies, as well as institutional structures. This brief literature review highlights that macroeconomic factors are critical in predicting the variability of stock returns. No standardized set of macroeconomic variables exist, despite the clear relationship between stock market and economic activities. However, inflation rate, exchange rate, interest rate, and unemployment rate are the most popular significant factors in order to explain stock market movements. There may be other influencing factors such as the transmission of shocks and psychological effects (using as proxy the consumer confidence index) in the determination of stock price movements. The present study also differs from previous ones by taking both sector and company data into account but for individual developed countries.

\section{METHODOLOGY AND DATA}

The present study uses factor models based on the APT model allowing including several factors into one regression which may influence stock returns. In this model, it is need to use previous statistical and economic analysis to determine which factors must be used as independent variables.

The econometric model used here obeys the following specification: 


$$
r_{i, t}=\alpha_{i}+\beta_{i, 1} F_{1, t}+\beta_{i, 2} F_{2, t}+\ldots+\beta_{i, k} F_{k, t}+\varepsilon_{i, t}
$$

where $r_{i, t}$ represents the return on stock i computed as the log difference between consecutive prices, $\alpha$ is the constant term, $\beta_{i}$ measures the sensitivity of a stock $i$ to a set of $n$ macroeconomic factors, $F_{n}$ indicates realizations of macroeconomic factors and $\varepsilon$ is the error term with an expected value of zero.

Daily data from stock market sector index data and 5 different individual companies' stock market data for each of the considered ten sectors for countries like UK, US, Australia, Japan and Germany from the period of March 1993 until February 2013 has been collected. In total we have collected data for 250 individual companies and 50 sector indices. The daily data was converted into monthly returns using the month last day of trading available data. The five companies considered for each sector were randomly selected where we have decided to collect from those companies for which we had more years of available data over the sample offered. Data for the considered representative sector indices goes from December 1992 until October 2012, which was also converted into monthly series. The sectors here analyzed are Basic Materials (BM), Consumer Goods (CG), Consumer Services (CS), Financials and Banks $(F ; B)$, Healthcare (HC), Industrials (I), Oil and Gas (OG), Technology (Tec), Telecommunications (Tel) and Utilities (U). When analyzing sector market indices the world index for that specific sector has been considered as the proxy for the market index. This data has been collected from several sources including countries official stock exchanges, their central bank, Eurostat, FRED, EIA, OECD statistics and others whenever necessary.

In the multifactor model, the researcher identifies which and how many factors are to be included in the regressions. The factors used in the present analysis were selected based on the literature review previously presented and which were considered to be the most representative. With respect to the number of factors Campbell et al. (1997) show that it is sufficient to use three to six factors in the model. Having this in mind, and for the US capital market, Chen et al. (1986) use as macroeconomic variables industrial production, inflation, risk premium, term structure, market index, consumption and oil prices. Macroeconomic variables used in the present work, can be classified into five groups of variables: reflecting general economic conditions, related to interest rate and monetary policy, concerning price level, considering investors behavior and concerning international activities. As such, we have used monthly oil returns, inflation rate, industrial production index, market interest rate, stock market index and consumer confidence index, variables collected individually for each of the countries under analysis. All price series have been converted into log returns and were denominated in US dollars.

Macroeconomic stability influences the stock market development and inflation. Inflation raises the general price level, reduces the real value of money and the expected cash inflow of an asset. Consistent with previous studies (Nacuer et al., 2007) inflation ( $\pi$ in tables) has been used as a measure of macroeconomic stability. We expect inflation to affect negatively both stock and sector indices. For some countries we use the direct inflation rate provided by 
the available data, while for others the consumer price index of the respective country (Hasan and Javed, 2009; Kuwornu and Owusu-Nantwi, 2011). Nacuer et al. (2007) found that macroeconomic instability has a negative and significant relationship with stock market capitalization. A nonlinear relationship among inflation and the development of the equity market is found by Boyd et al. (2001). They conclude that when inflation rises, the marginal impact on stock market development diminishes rapidly. In Yartey (2008), no significant relationship between inflation and stock market development was stated. Using an asymmetric model, Kolluri and Wahab (2008) examine the relationship between expected inflation and stock returns, concluding for a negative relationship during low inflation regimes, and a positive one during high inflation regimes.

Empirical research onto the relationship between financial sector development and economic growth is not consensual. The banking sector development was found to have a positive effect on economic growth (Christopoulos and Tsionas, 2004) as well as a negative one (Singh et al. 2011). The banking sector is important for stock market development as it provides investors with liquidity through credit and facilitating savings. Nacuer et al., (2007) and Yartey (2008) argue for the existence of a positive relationship between the development of the banking sector and that of the stock market. Yartey (2008) states that a very high level of bank sector development may have negative effects because stock markets and banks tend to substitute one another as financing sources. Stock markets and banks are considered as competitors in providing finance (Kemboi and Tarus, 2012). So, with a welldeveloped money market, the capital market may be overshadowed leading to a slower rate of development. Our measure of the banking sector is countries interest rates (IR in the tables). We know that high interest rates tend to decrease the present value of future cash flows. This reduces investment attractiveness and according to economic theory, also stock prices. The interest rate used here is the 3-month Treasury bill reference interest rate, one for each respective country. As such, we expect a negative sign between interest rates and stock returns. Li et al. (2010) use the US's Federal fund rate and Canada's overnight rate to study the effect of policy shocks on stock prices. Stock returns were found to be affected by monetary policy shocks in both countries, being this effect in the US more pronounced. Chang et al. (2011) conducted a study about monetary policy and stock returns using Federal funds rate, finding a small effect over stock returns. Gregoriou et al. (2009) used 3-month Sterling LIBOR futures as the proxy for monetary policy shocks in the UK market, finding a negative relationship between interest rate changes and stock returns.

The industrial production index has been used as a proxy for economic conditions and activity in previous studies. Here we use the industrial production (IP in the tables) growth rate for each respective country. Humpe and Macmillan (2009) used co-integration analysis to show a positive relationship between the industrial production index and stock prices in both the US and Japanese market. The authors emphasize that the industrial production index can be a better proxy for economic conditions in general. Also Benakovic and Posedel (2010) use the industrial production index given that GDP data is only published on a quarterly basis. It is expected a positive relationship between industrial production and stock returns.

Revista de Estudos Sociais | Ano 2014, N. 31, V. 16, Pag. 9 
Globalization turned international activities important. Exchange rate is one of the most important factors in this group, especially for the countries that depend to a great extent on international trading activities as the ones we are analyzing here. In the present study we do not use exchange rates as independent variables directly but in a disguised way, used to transform all the needed series into dollar prices.

Also oil prices have been used as an independent variable. The oil price (OP in the tables) series used here is the West Texas Intermediate (WTI), monthly spot price. Some studies have focused on oil prices, considered as a proxy for cost-push inflation. Oil price rises increase the uncertainty in capital markets and the risk of inflationary pressures in the economy (Benakovic and Posedel, 2010), by increasing companies costs like transportation and production, while may reduce their profits and consequently stock returns. So, oil prices are expected to have a negative influence over capital markets. Faff and Brailsford (1999) for Australian equity returns, show that sensitivities to oil prices vary across industries, finding a negative effect over the oil and gas, paper, packaging and transportation industries. Kilian and Park (2009) have studied the effect of oil demand and supply price shocks on stock returns, finding that only oil demand shocks have a significant impact on stock returns. For Russia, Fedorova and Pankratov (2010) used Brent oil price to analyze the influence of macroeconomic factors on stock returns, revealing that Brent is the macroeconomic factor that most affects stock returns.

Following Benakovic and Posedel (2010), macroeconomic variables cannot comprise all the information available in capital markets, but stock prices react to information released. They suggest the inclusion of financial market variables like the stock market index in the factor model. Also Chen et al. (1986) use this variable and we will use each country individual stock market index (MI in the tables) representative as an independent variable. Given that the overall market performance positively influences stock returns, we expect a positive relation between stock returns and the market index representative.

Finally, we have also included the consumer confidence (CC in the tables) index for each respective country into our multifactor model. Consumer confidence acts as a proxy for individual investor sentiment, given that it attempts to gauge consumers' feelings about the current economy condition and their expectations about the economy's future direction. Investor's sentiment, or positive (negative) expectations, has a determining role in stock market price movements (Brown and Cliff, 2004) and affect economic growth. Lin et al. (2009) found that changes in the consumer sentiment are contemporaneously associated with market returns, concluding that positive (negative) changes in sentiment tend to drive aggregate stock prices higher (lower) in the same period. These links also been reported previously by Otoo (1999) and Jansen and Nahuis (2003) who studied the European market to find that stock returns and changes in sentiment are positively correlated, none using individual companies' data. So, a positive relationship between these two variables is initially expected. 


\section{EMPIRICAL FINDINGS AND POLICY IMPLICATIONS}

To consider all the variables under analysis we have performed more than 300 multiple regressions, being stock returns the dependent variable while the macroeconomic variables described above are the independent ones. These regressions provided six different coefficient sensitivities for each regression, which estimate individual stock or index sector returns sensitivities to changes in the set of macroeconomic factors. As such, results are interpreted as the monthly change in the stock or index sector stock return when a particular macroeconomic factor changes by one percentage point keeping all other variables constant. Results of the regression analysis are presented in table 1 , one panel for each of the countries under analysis. Although we have performed regressions over 250 individual company stocks, to save space we present only the results for one randomly selected company for each sector and for each country, given that results were similar among the five companies considered, and thus able to be generalized. All other results will be provided upon request.

Table 1 shows the results obtained for one of each of the 5 considered companies by sector, randomly selected, for each of the countries. It is clearly evident that it is the stock market index which most affects company individual stock returns and in a positive manner as predicted, independently of the sector or country analyzed. The obtained sign is positive and statistically significant as initially predicted. So, changes in the market index return impact economies as a whole, without distinction of the sector for developed economies. The only exception is Germany. Portfolio investors must then be aware that they can use market index return movements to forecast companies' returns. In Germany the positive influence is only verified in sectors like basic materials, consumer goods, consumer services and financials, and somehow surprising results given the financial literature which emerged in this context.

The interest rate variable, in Banks and Basic Materials indicates a positive relationship with company stock returns, which is also observed for the variable inflation in the UK market for companies of the Oil \& Gas and Telecommunication sectors. These values contradict our initial prediction with respect to the sign relationship among variables. But, as inflation increases, stock prices will consequently increase following the general price pattern. So, this positive sign may be due to the market capitalization increase due to inflationary causes (Kemboi and Tarus, 2012). In Australia, the interest rate only influences positively the health care individual companies sector, whereas inflation only revealed a positive influence over the consumer goods and the oil \& gas companies considered. Interest rate reveals to have a negative sign over the representative company considered for the health care sector in Germany, which is consistent with our prior assumptions about the influence of interest rates sign over stock returns. However, this negative influence is not generalized for all the countries under analysis as previously observed. In all the other countries, when for some specific sectors the sensitivity of the interest

Revista de Estudos Sociais | Ano 2014, N. 31, V. 16, Pag. 11 
rate, or else its coefficient revealed to be statistically significant, we see a positive sign. These results are contrary to our initial expectation about the two variables relationship but are in accordance with those obtained by Benakovic and Posedel (2010) for the Croatian market, also considering individual companies results. Given these weak results around the inflation rate and noticing that also Kuwornu and Owusu-Nantwi (2011) and Mohammed et al. (2008) obtained a positive sign, we could similarly to these authors justify this positive impact due to the inadequacy of the hedging role of stocks against inflation. As such, for the companies in those specific sectors and countries where the inflation rate reveals to be positive stocks cannot be used as a hedge against inflation. In this case, higher expected returns are needed for higher inflation rate. Still, our positive results contradict those obtained by Kandir (2008).

Consumer confidence shows a higher impact for UK and Australian individual company stock investors, no effect over German investors and a residual effect over utilities company stocks in the USA and Basic Materials in Japan. Similar to Otoo (1999), Jansen and Nahuis (2003) and more recently Lin et al. (2009) we can also state that changes in the consumer sentiment are contemporaneously associated with market returns. So, positive (negative) changes in sentiment tend to drive individual companies stock prices higher (lower) in the same period, at least for company sector returns like consumer services, financials, industrials and utilities (for Australia), also influencing telecommunications and oil \& gas in UK.

Lin et al. (2009) empirical results based over multivariate analysis, causality tests and VAR models, suggest that changes in sentiment capture variation in average returns in the energy, financial, industrial, information technology and material sectors, which should be somehow expected given that this valuation of stocks tend to be more subjective. Returns in the consumer, health care, property trusts, telecommunication and utility sectors are not affected robustly by sentiment given that these are matured sectors characterized by limited growth and stable earnings and are thus less sensitive to changes in sentiment. Also, given that we are only analyzing developed countries, the idea that some sectors may not be affected by sentiment due to their maturity stage isn't confirmed by our results given that sentiment affects significantly and positively individual company's stock returns from the utilities sector. In our estimations, when we have a negative sign influence we have no statistical significance and so results may be ignored and generalized to state that the consumer confidence index is an important variable to be considered when analyzing the effects of macroeconomic variables over stock returns, at least for some markets. However, there have been reduced efforts in this sense in the empirical literature to establish this relationship among the two variables. In fact, stock prices should be affected by investor's expectations, when these respond quickly to new economic and political news released to the market. Kemboi and Tarus (2012) state that higher investors confidence and industrial production may be related to higher income, because investors willingness to save and invest are proportional to disposable income increases. 
Table 1: UK, USA, Australia, Germany and Japan, individual companies stock returns by activity sector regression results

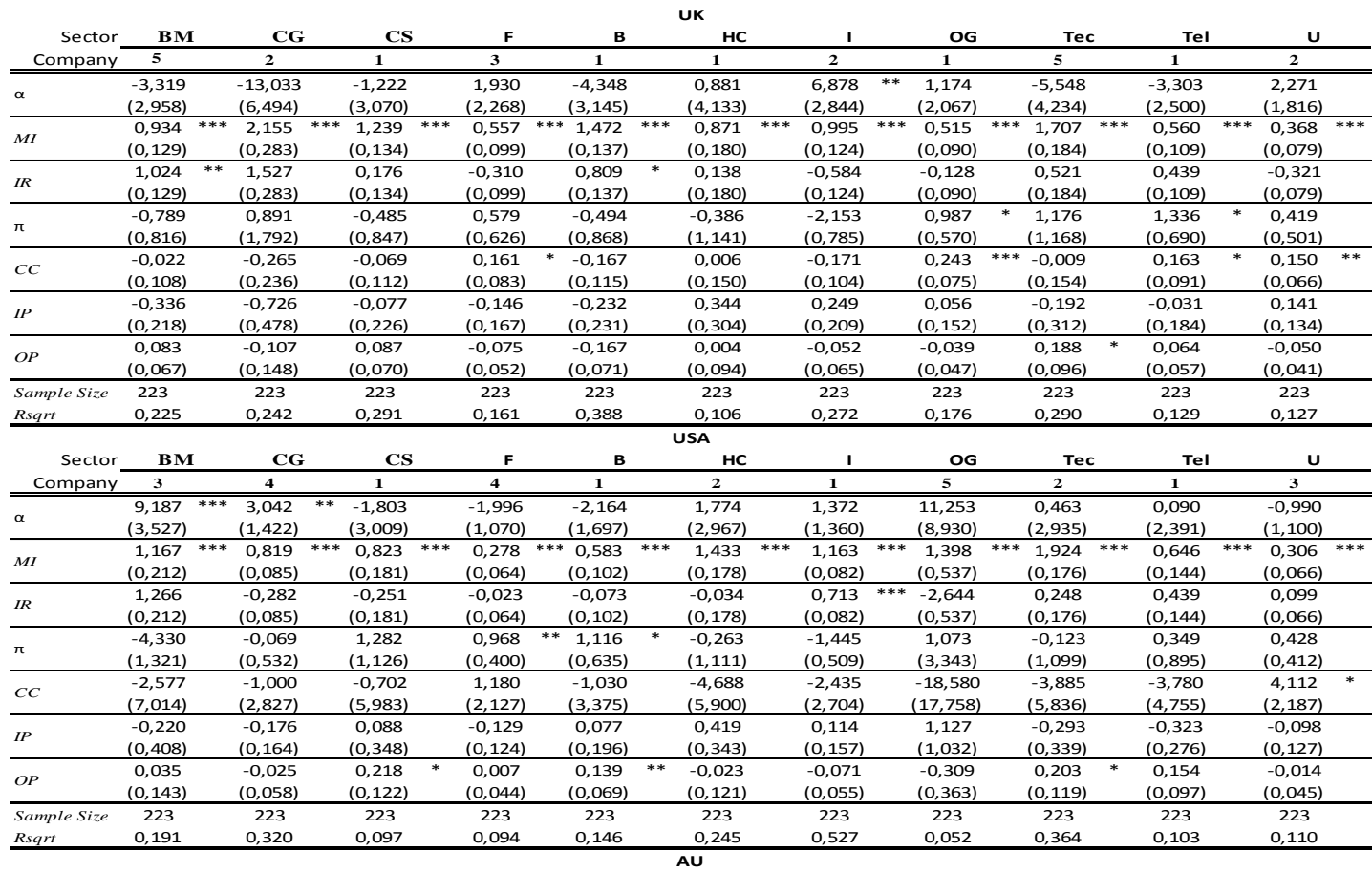

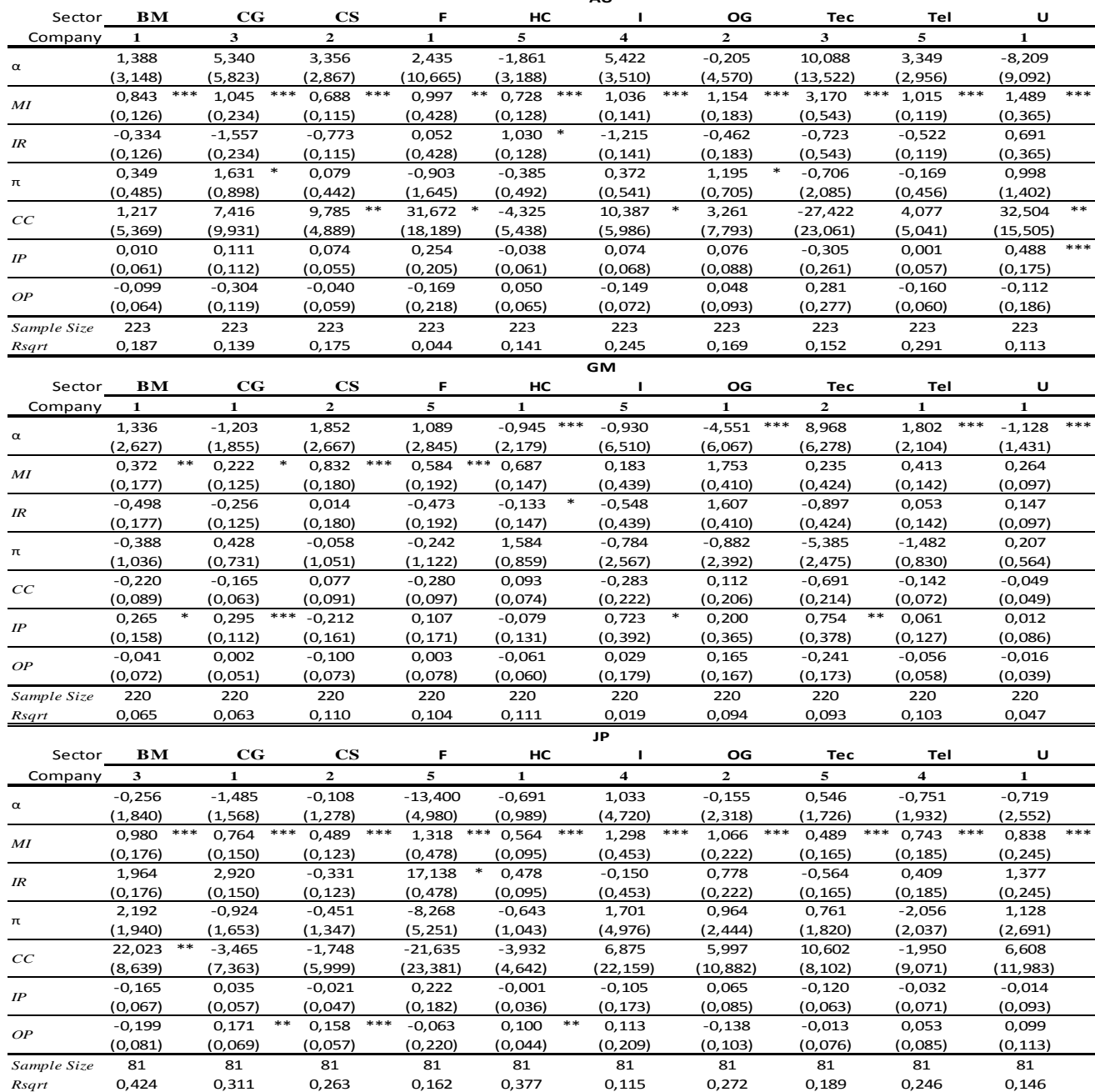

Source: Prepared by the author

Revista de Estudos Sociais | Ano 2014, N. 31, V. 16, Pag. 13 
However, for UK, USA and Japan we see no influence of industrial production over company returns. Results indicate only a positive and significant influence for companies in the utilities sector in Australia and for those in basic materials, consumer goods, industrials and technology for Germany. As such, in the German market policy makers should encourage these companies sectors for the promotion of industrial production as a way to develop securities market. These are very developed sectors in Germany and have highly grown in the period considered. In fact, Germany is one of the leading countries of the actual European Economic and Monetary Union. As stated by Tangjitprom (2012) production index growth is consistent with the average growth of firms' sales and cash flows. In our work we cannot confirm the findings of a positive relationship between industrial production and stock prices for the USA and Japan of Humpe and Macmillan (2009) for both individual companies and sectors (see table 2 results also). In the Australian market, we have only been able to see a statistical significant relationship between industrial production and companies in the utilities sector.

Previous authors state that oil returns have asymmetric effects depending on the sector under analysis. Here we have only attained a positive significant relationship in the UK for the technology sector. In the US market oil prices seem to negatively affect consumer goods, health care, industrials, oil and gas and the utilities sector, but these results are not statistically significant. Curiously, and similar to the UK, German and Japanese markets, oil price increases seem to decrease the oil \& gas individual companies returns. We should expect the opposite sign effect in this specific sector, and given that these results are statistically insignificant we won't present more detailed interpretations. German usage of renewable has also been increasing in the sample period. As such, we may justify the fact that oil prices do not represent a significant influence over company stock returns on the basis of this interpretation, but a much deeper analysis is needed in this sense. We may also observe that it is for the Japanese market that oil prices most influence, and in a positive fashion, sector company returns like those of consumer goods, consumer services and health care. In fact we should expect that besides the market index, oil prices should have a more statistically significant relationship with each of the other companies sectors. In the case of Japan this positive influence in these specific sectors is mostly due to production and transportation costs influences, which will thus influence stock returns in the increasing sense. The Energy Information Agency (EIA) in 2012 states that Japan is the world's third largest net importer of oil, and relied on oil imports to meet about $42 \%$ of its energy needs in 2010. This dependency justifies the increased significance of oil in these company returns for these specific sectors in Japan.

But, our initial prediction for oil prices was that of a negative influence over stock returns. We were initially expecting that an increase in the price of oil would depress economic activity, by means of lower real economic activity (Kuwornu and Owusu-Nantwi, 2011), and so a negative sign would be justified. Our results for this positive sign are consistent with those obtained by Benakovic and Posedel (2010). While discussing their results the authors attribute differences in significance obtained for Croatia and those of Chen et al. 
(1986) for the US market, who found a negative impact, by stating that US capital market is one of the most developed markets in the world, respond quickly to all publicly disclosed information and to the fact they have less available data for Croatia. We have almost 20 years of monthly returns for developed economies and results were very similar to those obtained by Benakovic and Posedel (2010). Faff and Brailsford (1999) found negative effects over the oil and gas, paper, packaging and transportation industries. Although not statistically significant, we have obtained a negative relationship for companies in the consumer goods, financials, banks, industrials, oil \& gas and utilities sectors, which is consistent with the economic reasoning concerning this sectors nature, except that of oil \& gas. As such, we cannot clearly state for the markets under analysis, that oil returns and company stock returns have a significant relationship, contrary to Kilian and Park (2009) and Fedorova and Pankratov (2010), except for companies in the sectors already identified in Japan.

For both the UK and US markets we have considered banks as an individual sector within the financial sector and for both we can only state that there is a positive influence of the market index over stock returns. Moreover, only the utilities sector in the US seems to be positively and statistically influenced by the consumer confidence index and the inflation rate results indicate a positive influence of this one over the financials and banks sector company returns.

We can also observe from table 1 that $R^{2}$ values are all very small for the generality of the countries, sectors and companies considered. Given the results that we have attained for individual companies we may conclude that other type of influence can be behind these relationships. In fact, we can have disguised lagged effects or even clockwise effects, meaning that we should also explore the dynamic and nonlinear effects which might be happening among these variables. We could for example have oil prices influencing inflation and interest rates, and only then these will influence industrial production and stock returns, or some similar kind of relationship, which should be interesting to explore in future works. Moreover, it should also be interesting if we could separate the analysis between the pre and post-worldwide financial crisis to see if results change given that also previous authors point for separate effects. One example is that of Gregoriou et al. (2009) which found a negative relationship between interest rate changes and stock returns before the credit crisis period; however, the relationship reversed to a positive one during the credit crisis.

Moving forward in our analysis, and in order to see if results change by using general stock market sector indices returns instead of individual company one's, we will next test the significance and explanatory power of all the macroeconomic variables previously described plus the world respective stock index sector return (as representative of the market index) over sector stock index returns. In total ten for each of the countries analyzed which sums 50 sector indices analyzed. Table 2 presents all country sector indices results obtained.

Regarding sector stock market indices, for all countries we see that the world respective sector return index is the one which most influences positively individual country sector returns. In fact, for the UK market only this variable 
seems to have a statistically significant impact over sector index returns. Unfortunately, we haven't got many different results as those already obtained for individual companies operating in each of these sectors. As presented, only the macroeconomic variables inflation, oil prices and industrial production seem to have effects over sector stock market indices, and for all variables whose results revealed to be statistically significant seem to indicate that there exists a positive influence of these over the sector indices. For the Australian market inflation only exerts a positive influence over the industrials sector and for the US market it influences positively the health care, industrials and oil and gas sectors. As for industrial production results seem to indicate that there is only a positive impact of this variable over sector stock index returns for Germany and Japan. While in Japan the impact is only significant over the oil and gas sector, for Germany this is confirmed for basic materials, consumer goods and financial sectors. Finally, oil prices affect sectors positively like financials in US, Germany and Japan and that of consumer goods in Australia, Germany and Japan. It also affects positively basic materials in Germany, as well as consumer services, oil and gas and the utilities sector in Japan.

In face of the attained statistically insignificant results, which revealed to be even worse in terms of sectors than for individual companies stock returns, we tried to see if these results are due to a bad choice of macroeconomic variables or if these depend upon periods or model choice. In order to answer this we have applied moving average windows estimation technique for periods of 60 month windows for each of the sector stock indices returns in each of the countries analyzed.

In the following we will only present beta estimates for two sectors in the UK market: financials and consumer goods. However, the same general conclusions to be taken for both sectors and to this specific country are generalized to the rest of our sample. Results are showed in figure 1 (for the financial sector - a - and for the consumer goods sector - b). These beta coefficients estimates representations are based on moving windows estimates, where regressions for each index are done considering the same explained and explanatory variables for small samples of 60 months each. As such, we are able to obtain beta coefficients estimates for each macroeconomic variable considered through time given that each month the last 60 monthly observations are used to compute these same coefficients evolution through time. So, we can also observe if results statistical insignificance is always verified through time intervals samples of 60 months or even if the model specification used is the most correct one. 
Table 2: Sector index stock returns by activity sector and country regression results

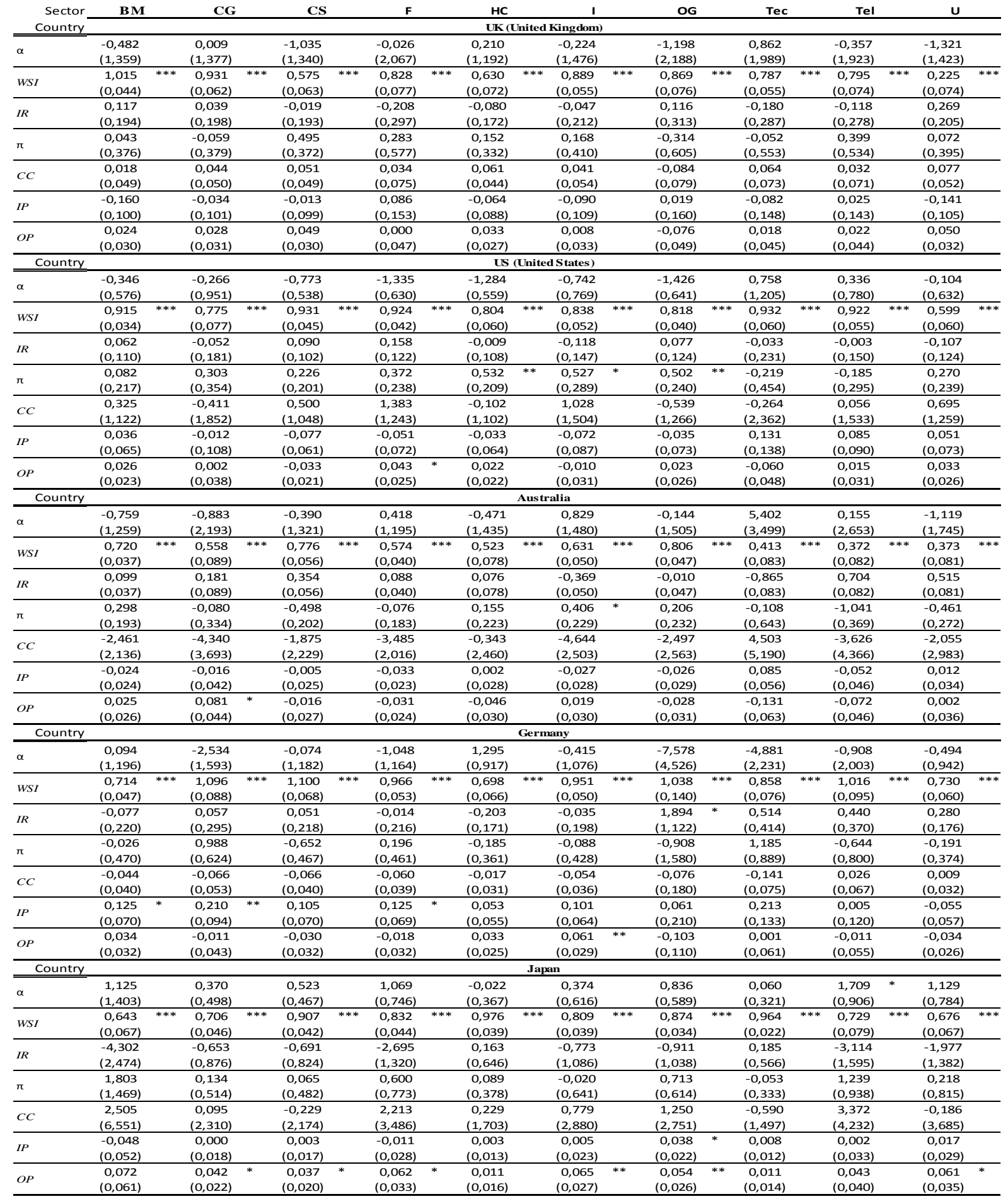

Source: Own regression results. NOTE: The estimation method used in this multifactor model has been the OLS with White heteroskedastic correction. Standard errors are in parentheses. ${ }^{* * *}=$ significant at $1 \%$ level; ${ }^{* *}=$ significant at $5 \%$ level; ${ }^{*}=$ significant at $10 \%$ level. $\alpha$ represents the constant term; WSI the world sector index; IR the interest rate; $\pi$ the inflation rate; CC the consumer confidence; IP industrial production and OP the oil return. The sectors here analyzed are Basic Materials (BM), Consumer Goods (CG), Consumer Services (CS), Financials and Banks (F; B), Healthcare (HC), Industrials (I), Oil and Gas (OG), Technology (Tec), Telecommunications (Tel) and Utilities (U). 
As observed in figure 1, macroeconomic variables chosen do have effects over the specific sector stock market index return, but these effects change through time and that's why the aggregate effect presented previously turned out to be so highly statistically insignificant in general. So, we do have a relationship between macroeconomic variables although it is not a stable relationship through time because it changes of sign throughout time. This means for example that until 2003 the interest rate has negatively influenced the financial sector returns but between 2003 and 2004 this effect turned out to be positive, or else that oil prices do not seem to have any statistical significant effect over the financial sector for the entire period for the UK market. So, changes of sign are not linear because for several periods we have high significance and for others there is simply no significance verified between the variables under analysis. Curiously in the consumer goods sector, oil prices also seem to have no effect over sector stock returns, but conclusions to be taken from here need a deeper analysis. But for both sectors we have a positive and highly significance of the market index over sector returns as also previously concluded for the entire period.

Turning to the consumers sector returns beta coefficients estimates, we see that inflation rates had a negative effect over the sector index between 2004 and 2005 and again in the recent years of the financial world crisis. In that same period of 2004 we observe the interest rate positive effect over this sector, while consumer confidence and the production index impact have periods of unstable effects. This instability is not captured through a simple OLS model and we need to use nonlinear models or even different time samples in order to be able to take deeper and better conclusions.

Figure 1: Moving windows estimates for 60 months time intervals regressions: financial (a) and consumer goods (b) sector stock market index in the UK market

a) Financial sector
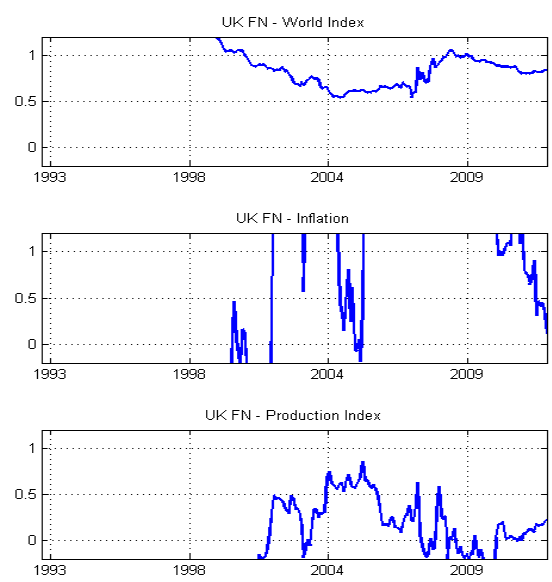
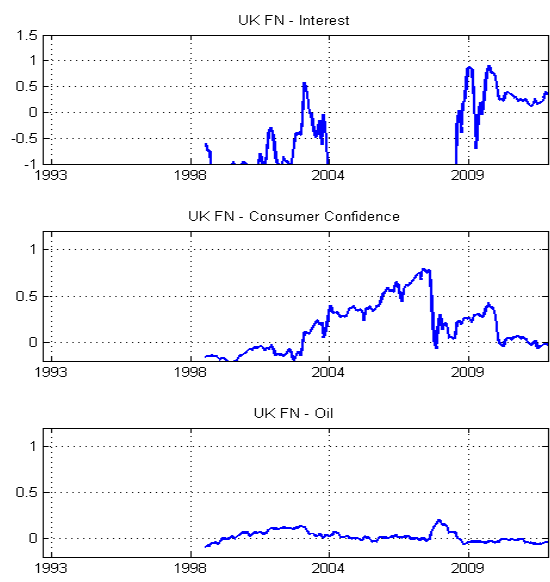

b) Consumer Goods sector 

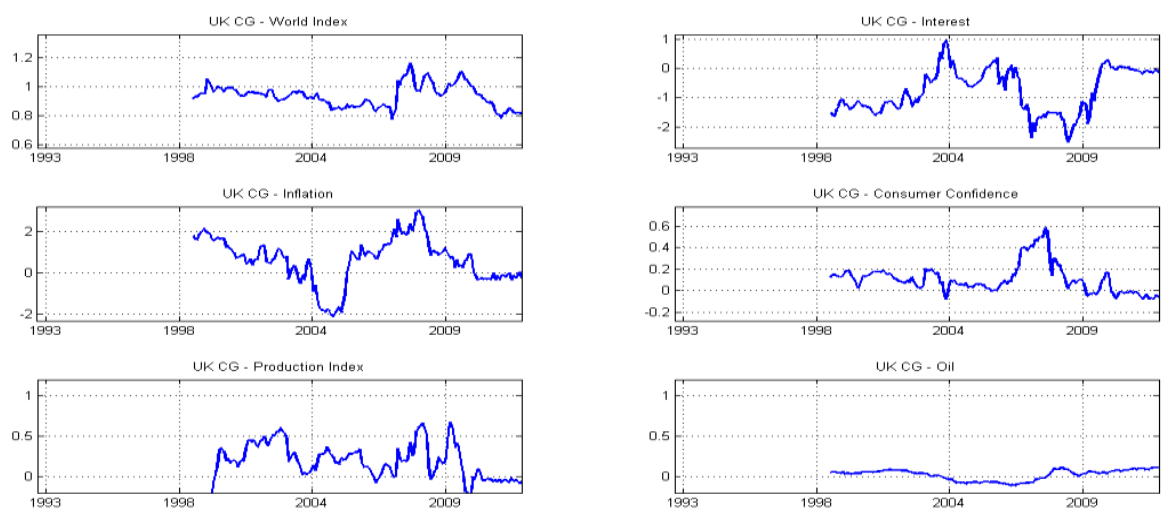

Source: Own produced results. Notes: These figures presents beta coefficients estimates obtained for the financial (a) and consumer goods (b) sector index stock returns in the UK market, by using small moving windows regression estimates based on the last 60 months observations. The $x$ axis shows the betas evolution through time for the time period analyzed and also into account in each month estimate the previous 60 months values. The y axis represents the beta coefficients estimated values which goes from 0 (no sensibility of the stock index sector return to that macroeconomic variable) until 2 (high sensibility of the stock index sector return to that macroeconomic variables - positive or negative).

This type of conclusions leaves room for a deeper understanding of these variables effect over companies and sector index stock returns. Given that both figures reveal the stability or instability of beta coefficients estimates throughout the sample period and this instability has been observed, future research should consider these different periods analysis and also the use of nonlinear models able to capture these unstable effects through time among variables.

\section{CONCLUSION}

This work analyzes the effects of macroeconomic variables like inflation rate, interest rates, industrial production, consumer confidence, oil prices and the market index over both individual companies stock returns, considered by sector and for stock market index sectors for five developed countries (UK, US, Germany, Australia and Japan) using monthly data series for the period between March 1993 and February 2013. For the analysis we have used a multifactor APT model, having performed more than 300 individual regressions. Our findings have beneficial implications for policy makers who are responsible for managing the economy but also for individual company's managers and portfolio investors.

Results seem to indicate that movements in the market index return are the best predictor to forecast stock returns of both individual companies and sectors in developed economies. At the end, we were not able to establish a unique relationship between the other macroeconomic variables under analysis and stock returns. Results cannot be generalized in terms of sectors and countries and this fact can be attributed to their different market characteristics. Moreover, companies returns sensitivities to macroeconomic variables change 
of sign depending over the sector and country under analysis. Despite this fact, empirical results suggest the importance of the inclusion of the consumer confidence index to explain macroeconomic impacts over stock returns, which has upon to now been somehow discarded from the emerged empirical literature over the issue. Interest rate revealed to have a positive effect for most of the companies and countries under analysis, when we should expect from economic and financial theory an opposite effect. As for general stock market country sectors indices also considered here we may conclude that inflation, industrial production, the market index and oil prices are the only variables able to explain some of the sector index returns, where all seem to have a positive effect. Finally, we shown that these insignificant coefficients estimates obtained are not due to a bad choice of repressors, but yes to the instability of beta coefficients estimates throughout time which leaves room for future work.

\section{REFERENCES}

Adam AM. and Tweneboah G. 2008. Macroeconomic Factors and Stock Market Movement: Evidence from Ghana. MRPA Working Paper 11256.

Akbar M., Ali S. and Faisal M. 2012. The relationship of stock prices and macroeconomic variables revisited: Evidence from Karachi stock exchange. African Journal of Business Management 6, 4: 1315-1322.

Benaković B. and Posedel, P. 2010. Do macroeconomic factors matter for stock returns? Evidence from estimating a multifactor model on the Croatian market. Business Systems Research 1, 1-2: 39-46.

Bencivenga VR. Smith BD. and Starr RM. 1996. Equity Markets, Transactions Costs, and Capital Accumulation: An Illustration. The World Bank Economic Review 10, 2: 371-396.

Berthelemy J. and Varoudakis A. 1996. Economic Growth, Convergence Clubs, and the Role of Financial Development. Oxford Economic Papers 48: 300-328.

Binswanger M. 2000. Stock market booms and real economic activity: is this time different? International Review of Economics and Finance 9: 387415.

Boyd JH. Hu J. and Jagannathan R. 2005. The Stock Market's Reaction to Unemployment News: Why Bad News Is Usually Good for Stocks. The Journal of Finance 60, 2: 649-672.

Boyd JH. Levine R. and Smith BD. 2001. The Impact of Inflation on Financial Performance. Journal of Monetary Economics 47, 2: 221-248.

Brockman P. and Chung DY. 2006. Index Inclusion and Commonality in Liquidity: Evidence from Stock Exchange of Hong Kong. International Review of Financial Analysis 15: 291-305. 
Brown GW. and Cliff MT. 2004. Investor sentiment and the near-term stock market. Journal of Empirical Finance 11, 4: 627-628.

Buyuksalvarci A. 2010. The Effects of Macroeconomics Variables on Stock Returns: Evidence from Turkey. European Journal of Social Sciences 14, 3: 404-416.

Campbell J., Lo A. and MacKinlay A. 1997. The econometrics of Financial Markets. Princeton University Press, Princeton, New Jersey.

Chang K-L., Chen N-K. and Leung CKY. 2011. Monetary Policy, Term Structure and Asset Return: Comparing REIT, Housing and Stock. The Journal of Real Estate Finance and Economics 43, 1: 221-257.

Chen N-F., Roll R. and Ross S. 1986. Economic Forces and the Stock Market. The Journal of Business 59, 3: 383-403.

Chen S-S. 2007. Does Monetary Policy Have Asymmetric Effects on Stock Returns? Journal of Money, Credit and Banking 39, 2-3: 667-688.

Christopoulos DK. and Tsionas EG. 2004. Financial Development and Economic Growth: Evidence from Panel Unit Root and Cointegration Tests. Journal of Development Economics 73: 55-74.

Czaja M-G. and Scholz H. 2007. Sensitivity of Stock Returns to Changes in the Term Structure of Interest Rates - Evidence from the German Market. Operation Research Proceedings: 305-310.

Durham JB. 2003. Monetary Policy and Stock Price Returns. Financial Analysts Journal 59, 4:26-35.

Erdem C., Arslan CK. and Erdem MS. 2005. Effects of macroeconomic variables on Istanbul stock exchange indexes. Applied Financial Economics 15: 987-994.

Faff RW. and Brailsford TJ. 1999. Oil price risk and the Australian stock market. Journal of Energy Finance and Development 4: 69-87.

Fama EF. 1990. Stock Returns, Expected Returns, and Real Activity. Journal of Finance 45, 4: 1089-1108.

Fedorova EA. and Pankratov KA. 2010. Influence of Macroeconomic Factors on the Russian Stock Market. Studies on Russian Economic Development 21, 2: $165-168$.

Flannery MJ. and Protopappadakis AA. 2002. Macroeconomics Factors Do Influence Aggregate Stock Returns. The Review of Financial Studies 15, 3: 751-782.

Garcia FV. and Liu L. 1999. Macroeconomic Determinants of Stock Market Development. Journal of Applied Economics 2, 1:29-59.

Gencturk M. 2009. The effect of macroeconomic factors on stock prices in financial crises period. The Journal of Faculty of Economics and Administrative Sciences, Suleyman Demirel University 14, 1: 127-136.

Gregorio A., Kontonikas A., MacDonald R. and Montagnoli A. 2009. Monetary policy shocks and stock returns: evidence from the British market. Financial Markets and Portfolio Management 23, 4: 401-410. 
Gupta R. and Reid M. 2013. Macroeconomic surprises and stock returns in South Africa. Studies in Economics and Finance 30, 3: 266-282.

Hasan A. and Javed MT. 2009. An empirical investigation of the causal relationship among monetary variables and equity market returns. Lahore Journal of Economics 14, 1: 115-137.

Hosseini SM., Ahmad Z. and Lai YW. 2011. The Role of Macroeconomic Variables on Stock market Index in China and India. International Journal of Economics and Finance 3, 6: 233-243.

Huang Y-C. and Chen H. 2011. The interactions among stock returns, the term structure of interest rates and economic activities: Evidence from Taiwan. African Journal of Business Management 5, 4: 1334-1342.

Humpe A. and Macmillan P. 2009. Can macroeconomic variables explain long term stock market movements? A comparison of the US and Japan. Applied Financial Economics 19, 2: 111-119.

Jansen WJ. and Nahuis NJ. 2003. The Stock Market and Consumer Confidence: European Evidence. Economics Letters 79: 89-98.

Jones CP. and Wilson JW. 2006. The impact of inflation measures on the real returns and risks of the US stocks. Financial Reviews 41: 77-94.

Kandir SY. 2008. Macroeconomic Variables, Firm Characteristics and Stock Returns: Evidence from Turkey. International Research Journal of Finance and Economics 16: 5-45.

Kemboi JK. and Tarus DK. 2012. Macroeconomic Determinants of Stock Market Development in Emerging Markets: Evidence from Kenya. Research Journal of Finance and Accounting 3, 5: 57-68.

Kilian L. and Park C. 2009. The Impact of Oil Price Shocks on the U.S. Stock Market. International Economics Review 50, 4: 1267-1287.

Kolluri B. and Wahab M. 2008. Stock returns and expected inflation: evidence from an asymmetric test specification. Review of Quantitative Finance and Accounting 30, 4: 371-395.

Kuwornu JKM. and Owusu-Nantwi V. 2011. Macroeconomic Variables and Stock Market Returns: Full Information Maximum Likelihood Estimation. Research Journal of Finance and Accounting 2, 4: 49-63.

Li YD., Iscan TB. and Xu K. 2010. The Impact of Monetary Policy Shocks on Stock Prices: Evidence from Canada and the United States. Journal of International Money and Finance 29, 5: 876-896.

Lin CT., Ho CC. and Hsu HS. 2009. Market Psychology and Aggregate Stock Returns: Evidence from Australian Consumer Sentiment. Review of Applied Economics 5: 67-81.

Marone H. 2003. Small African Stock Markets-The Case of the Lusaka stock exchange. IMF Working Paper WP/03/6. 
Maysami RC. and Koh TS. 2000. A Vector Error Correction Model of the Singapore Stock Market. International Review of Economics and Finance 9: 79-96.

Mohammad SD., Hussain A., Jalil MA. and Ali A. 2009. Impact of Macroeconomics Variables on Stock Prices: Empirical Evidence in Case of KSE (Karachi Stock Exchange). European Journal of Scientific Research 38, 1: 96-103.

Nacuer SB., Ghazouani S., and Omran M. 2007: The Determinants of Stock Market Development in the Middle-Eastern and North African Region. Managerial Finance 33, 7: 477-489.

Nishat M. and Shaheen R. 2004. Macroeconomic factors and Pakistani equity market. Pakistan Development Review 43: 619-637.

Otoo MW. 1999. Consumer Sentiment and the Stock Market. Board of Governors of the Federal Reserve System, Available at:http://www.federalreserve.gov/pubs/feds/1999/199960/ 199960pap.pdf.

Özlen S. and Ergun U. 2012. Macroeconomic Factors and Stock Returns. International Journal of Academic Research in Business and Social Sciences 2, 9: 315-343.

Pal K. and Mittal R. 2011. Impact of macroeconomic indicators on Indian capital markets. The Journal of Risk Finance 12, 2: 84-97.

Park J. and Choi BP. 2011. Interest rate sensitivity of US property/liability insurer stock returns. Managerial Finance 37, 2: 134-150.

Quadir MM. 2012. The Effect of Macroeconomic Variables On Stock Returns on Dhaka Stock Exchange. International Journal of Economics and Financial Issues 2, 4: 480-487.

Rjoub H., Tursoy T. and Gunsel N. 2009. The effects of macroeconomic factors on stock returns: Istanbul Stock Market. Studies in Economics and Finance 26, 1: 36-45.

Sayılgan G. and Süslü C. 2011. The Effect of Macroeconomic Factors on Stock Returns: A Study of Turkey and Emerging Markets. BDDK, Bankacılık ve Finansal Piyasalar 5, 1: 73-96.

Sharpe SA. 2002. Reexamining Stock Valuation and Inflation: The Implications of Analysts' Earnings Forecasts. The Review of Economics and Statistics 84, 4: 632-648.

Singh T., Mehta S. and Varsha MS. 2011. Macroeconomic factors and stock returns: Evidence from Taiwan. Journal of Economics and International Finance 2, 4: 217-227.

Sohail N. and Hussain Z. 2009. Long-Run and Short-run Relationship between Macroeconomic Variables and Stock prices in Pakistan: The Case of Lahore Stock Exchange. Pakistan Economic and Social Review 47, 2: $183-198$.

Tangjitprom N. 2012. The Review of Macroeconomic Factors and Stock Returns. International Business Research 5, 8: 107-115. 
Yartey CA. 2008. Determinants of Stock Market Development in Emerging Economies: Is South Africa Different? IMF working Paper-WP/08/32, Washington, International Monetary Fund.

Zhu B. 2012. The Effects of Macroeconomic Factors on Stock Return of Energy Sector in Shanghai Stock Market. International Journal of Scientific and Research Publications 2, 11: 1-4. 